\title{
EXTRACELLULAR MATRIX IN PARASITIC AND INFECTIOUS DISEASES
}

\author{
H. L. LENZI; J. A. LENZI; I. B. KERR; S. L. G. ANTUNES; E. M MOTA \& D. N. OLIVEIRA \\ Instituto Oswaldo Cruz, Departamento de Patologia, Caixa Postal 926, 20001 Rio de Janeiro, RJ, Brasil
}

Parasitism is a constant drama played in nature, where different biological species strive to gain those elements necessary for growth, maintenance, and reproduction from the surrounding environment as well from other organisms. (PérezTamayo, 1985). For survive the parasite interacts dynamically with the host, which usually built an inflammatory barrier or interface, aiming to limit the spreading of the parasites and their products to the entire organism. The nomenclature used in describing different aspects of the host-parasite relationship has a strong teleologic flavor (PérezTamayo, 1985) stressing the inflammation and the immunological response as a defense mechanism. The reductionist approach of biology first considered the antibody proteins (humoral response) and posteriorly some cells (cellular response) as the principal defenders. However the host responses against infection are at once local and systemic, nonspecific and specific, humoral, cellular and extracellular (Extracellular matrix - ECM). The local reactions in direct contact with the infectious organisms (inflammatory stimulus) are characterized by an acute and/or chronic inflammatory process, which is highly complex and built up with many cellular and extracellular components. The stimulus activates a primary effector system which produces mediators recruiting and activating a secondary effector system, thus augmenting the inflammation. The secondary mediators can act as further inflammatory stimuli, thus propagating the cycle (Raphael \& Metcalfe, 1986). The infectious stimulus to inflammation may be extremely brief or protracted. In chronic inflammation caused by many parasites, the tissue reaction loses its dominant exsudative pattern and becomes mainly proliferative, rich in fibroblast and components of the extracellular matrix. The two basic proliferative response resulting from the host-parasite relationship are the granuloma and the granulation tissue. These reactions are carried out by means of cell-cell and cellmatrix interactions and their cellular and extracellular elements exhibit structural and functional heterogeneity, creating different kinds of environment, which can limit or favor the maintenance of the parasitism. In this paper we will present some examples about the importance of the ECM in the host-parasite relationship.

\section{ECM AND ADHERENCE OF INFECTIOUS ORGANISMS}

A crucial event in the initiation of many infections involves the adherence of infectious organisms to cells of the host (Reed \& Williams, 1978). Peterson et al. (1983) using hyperimmune antifibronectin serum as a probe revealed the ability of virulent treponemes (Treponema pallidum) to avidly bind fibronectin from a complex medium such as plasma. No acquisition of host macromolecules was evident by the avirulent spirochete, T. phagedenis, biotype Reiter.

Cell fibronectin binds to Staphylococcus aureus via a site in the $\mathrm{NH}_{2}$-terminal, $27-\mathrm{Kd}$ fragment of fibronectin (Mosher \& Proctor, 1980). Fibronectin can clump a variety of $S$. aureus strains but not $\mathbf{S}$. epidermidis (Esperden \& Clemmensen, 1981; Mosher, 1980). Fibronectin binds also to streptococci via bacterial lipoteichoid acid (Courtney et al., 1983), and can mediate the attachment of streptococci to neutrophils (Simpson et al., 1982) and epithelial cells in vitro (Abraham et al., 1983). Wyler et al. (1985) stablished that live Leishmania spp. could bind iodinated human plasma fibronectin in vitro. Furthermore, they observed that both amastigotes and promastigotes preferentially bount to glass coverslips that had been coated with fibronectin than with another, unrelated, protein. In parasite-monocyte co-cultures the addition of rabbit antiserum to human plasma fibronectin reduced by as much as $63 \%$ the attachment of amastigotes to human monocytes. Uptake of amastigotes was reduced $54 \%$ by the addition of antiserum. In the case of S. aureus, not only has specificity of fibronectin binding been demonstrated, but a candidate receptor on these bacteria has been identified (Ryden et al., 1983). Wirth and Kierszenbaum (1984) showed that fibronectin increases the association of Trypanosoma cruzi trypomastigotes with mouse peritoneal macrophages. Ouaissi et al. $(1984,1985)$ reported similar observations using trypanosome-infected 3T3 fibroblast monolayer cultures. Ouaissi et al. (1986; 1986a) identified a putative trypomastigote receptor for fibronectin and also determined that the same domain that binds fibronectin to mammalian 
cells probably is involved in binding the molecules to trypanosomes. Recently, Noisin \& Villalta (1989) showed that $T$. cruzi amastigotes also present receptors for human fibronectin. In the presence of physiological concentration of fibronectin, these receptors appear to increase the binding to and uptake of amastigotes by both murine macrophages and human monocytes. The fact that $T$. cruzi amastigotes (Noisin \& Villalta, 1989), trypomastigote (Ouaissi et al., 1984; Wirth \& Kierszenbaum, 1984) and epimastigote (Peyrol et al., 1987) forms present receptors for fibronectin molecule, indicate that fibronectin receptors are present on all stages of this parasite, regardless of their invasive capacities. This molecule may therefore play a significant role in increasing the attachment and incorporation of intracellular forms of $T$. cruzi, released from bursting infected cells, by macrophages and monocytes at the level of chagasic tissue lesions (Noisin \& Villalta, 1989).

Compared with fibronectin, little work has been published concerning the interaction of laminin and type IV collagen with bacteria and parasites. Speziale (1982) reported that laminin binds to $E s$ cherichia coli but not $S$. aureus, suggesting that laminin may be an important substrate for bacterial adherence and interacts distinctly from fibronectin with bacteria. Vercellotti et al. (1985) demonstrated that gram-positive, but not gram-negative, organisms avidly bind to matrix-protein-coated surfaces and that a representative gram-positive organism, S. aureus, aggregates in the presence of fibronectin, laminin, and type IV collagen. Lopes et al. $(1985,1988)$ have recently characterized a laminin receptor on the surface of $S$. aureus as a 52-Kd protein. In Trichomona vaginalis another receptor to laminin was also identified as a 118-Kd protein (Silva Filho et al., 1986).

Studies have shown that sera from patients with Chagas' disease or American Cutaneous Leishmaniasis contain distinct antibody titers against laminin and nidogen (Avila et al., 1984; Szarfman et al., 1982; Avila et al., 1986). Bretaña et al. (1986) using immunogold technique employing a specific anti-laminin antibody found laminin located in $T$. cruzi trypomastigotes on the external surface of the plasma membrane, close to the sites where the flagellar veil attaches to the plasma membranes. Laminin immunoreactivity, was rapidly lost when trypomastigotes were cultured in liquid medium and no reactivity was found in fresh epimastigotes. Promastigotes and amastigotes of American Leishmania spp. also showed a specific localiza- tion of laminin immunoreactivity, this being limited to the lips of the flagellar pocket and to the parasitic side exactly opposite to the flagellar exit. Bretaña et al. (1986) suggest that laminin-like proteins could facilitate trypomastigote-host cell interaction or movement through small blood vessels. Towbin et al. ( 1987) provided evidence that circulating antibodies to mouse laminin in Chagas' disease, American Cutaneous Leishmaniasis, and normal individual recognize terminal galactosyl ( $\alpha$ 1-3)-galactose epitopes.

Thrombospondin, another adhesive glycoprotein, binds falciparum malaria parasitized erythrocytes and may mediate cytoadherence. Aotus monkey or human erythrocytes containing Knobby $\left(\mathrm{K}^{+}\right)$but not Aotus erythrocytes containing Knobless strains of Plasmodium falciparum bind to immobilized thrombospondin (Roberts et al., 1985; Howard \& Sherwood, 1986).

\section{ECM AND PENETRATION OF INFECTIOUS ORGANISMS}

In order to become pathogenic the majority of the parasites and infectious agents must be capable of penetrating the different epithelial coverings of the organism. Other parasites bypass this step completely as part of their life cycle: malaria, yellow fever, and trypanosomiasis are perfect examples of parasites that are delivered into the circulation of the host by their respective vectors and that have no problems of penetration at all (PérezTamayo, 1985). During the process of penetration into the body or invasion into the tissues, the infectious organisms must transverse two types of extracellular matrix barriers: basement membranes and interstitial stroma. The infectious agents, like the tumors (Liotta et al., 1983), can modify the extracellular matrix in the following three ways: 1 . Degradation of matrix components associated with invasion; 2. Desmoplastic reaction, i.e., increased production of matrix components by host cells in response to the presence of the extraneous organisms and 3. Parasitic synthesis of matrix-like components.

The initial step in infection of the mammalian host by Schistosoma mansoni is invasion of intact skin by the cercariae. To gain access to the vascular system, cercariae must cross the epidermal basement membrane, the dermal connective-tissue extracellular matrix, and finally an endothelial-cell basement membrane (Lewart \& Lee, 1954; Stirewalt, 1974). During migration, schistosome 
cercariae transform into schistosomulae. Most of the proteolytic activity of invading larvae is due to the preacetabular gland proteinase of the cercariae, which diffuse widely ahead of the invading larvae (Stirewalt, 1982). Nevertheless, other surfaceassociated proteinases of the schistosomule in concert with the cercarial enzyme may facilitate subsequent vascular invasion (Auriault et al., 1982; Keene et al., 1983). The proteinase of cercariae degrades water-insoluble elastin and is thus classified as an elastase. Additional substrates include: proteoglycan, gelatin, laminin, fibronectin, keratin, and types I, IV and VIII collagen (Pino-Heiss et al., 1986; McKerrow et al., 1985 and 1986; Newport et al., 1987).

A collagenase has been described in pathogenic amebas, which is absent in nonpathogenic strains and which correlates fairly well with the virulence of the parasite (Muñoz et al., 1982; Gadasi et al., 1983).

To complete the vertebrate phase of the life cycle of S. mansoni, eggs must pass out of mesenteric venules and transverse a portion of the bowel wall before leaving the host by fecal excretion. This subject deserved attention of the researchers for many years and still the "metastatic capability" of the $S$. mansoni eggs is an intriguing question. Kloetzl $(1967 ; 1968)$ postulated that proteolytic enzymes released by the developing miracidium diffuse through pores of the eggs and facilitate the eggs passage through blood vessels and bowel walls. However, Pind-Heiss et al. (1985) did not detecte elastase. and collagenase activity in $S$. mansoni eggs and miracidia, supporting the contention of Ash \& Dresden (1979) that the collagenase activity of live eggs reported previously (Smith, 1974) was due to bacterial contamination. Torres \& Pinto (1945) suggest that $S$. mansoni egg release to the feces is due to the inflammatory process surrounding the eggs. Doenhoff et al. $(1978 ; 1981)$ and Dunne et al. (1983) provided the first evidence that the host immune system is intimately involved in the excretion of $\mathrm{S}$. mansoni eggs. Immunosuppressed mice have a reduced rate of faecal egg excretion, but when serum from donor mice with a chronic infection is injected into immunosupressed animals faecal egg excretion is partly restored; transfer of lymphoid cell is even more effective in this respect (Doenhoff et al., 1985; 1986). Damian (1987) proposed that the granuloma is the agent of translocation of the eggs to the lumen of an intestinal cript, due to the mobility of $\mathrm{T}$ and $\mathrm{B}$ lymphocytes, plasma cells, eosinophils, neutrophils, fibroblasts, macrophages and multinucleated giant cells. In fact, Lenzi et al. (1987), analising intestinal serial sections, observed that the eggs released to feces were always wrapped in inflammatory cells, specially eosinophils. This observation allow us to offer the following explanation: 1) Only during the exsudative phase of the granuloma, when there is

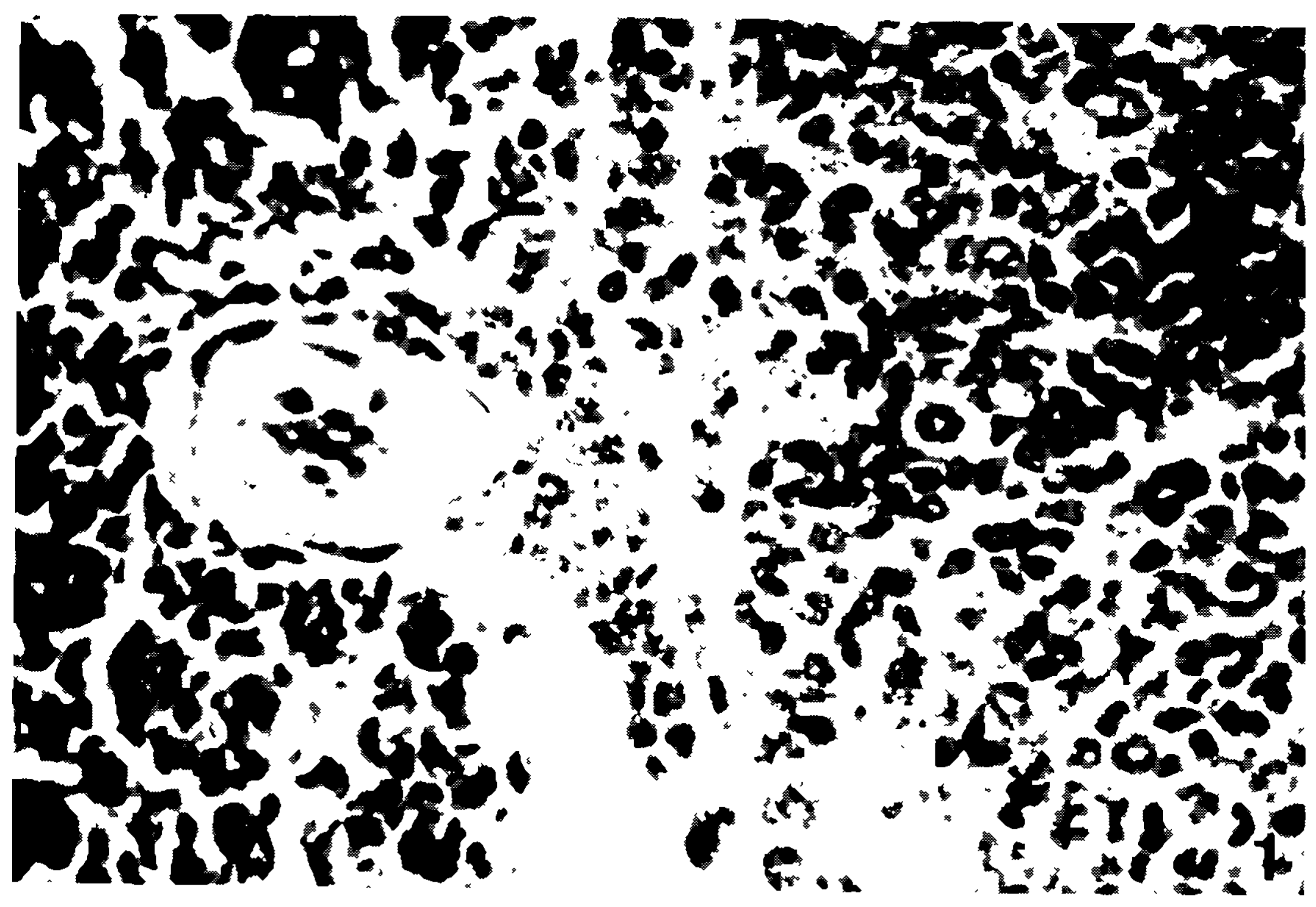

Fig. 1: Schistosoma mansoni egg attached to a portal vein by a cellular monticule composed by eosinophils and monocytes. HE X 500 . 
a strong peri-ovular destruction of the intestinal extracellular matrix the eggs have a chance to be released to the feces; 2 ) Products of the eosinophils alone or together with those of monocytes/macrophages are responsible for the corrosion of the basal membrane and the destruction or detachment of the superposed epithelial cells, thereby opening channels for the passage of the eggs to the intestinal lumen; 3) During the exsudative stage of the granulomas, collagenase, elastase and nonspecific protease production by granuloma macrophages/eosinophils destroy the fibers of the extracellular matrix of the intestinal chorion creating an afibrillar and easily penetrated environment for the eggs, thus allowing them to be passively ejected to the feces by intestinal peristalsis. A comparison of neutral protease (collagenase, elastase) levels within the granulomas and granuloma secretions showed that the large granulomas of acutely infected mice contained and secreted more enzymes than their smaller immunomodulated counterparts (Truden \& Boros, 1985).

We suggest that even the passage of the eggs from the vessels to the tissues is due to similar mechanisms, i.e., destruction of vessel wall by products of inflammatory cells surrounding the eggs (Figs 1 and 2). Mechanical irritation of the endothelium by the eggs themselves appears to be a non relevant phenomenon.

\section{ECM AND INFECTIOUS AND PARASITIC GRANULOMAS}

Granulomas, unlike granulation tissue which is rich in vascular neoformation, is usually an avascular structure. It appears that the granuloma is under the balanced influence of angiogenic stimulation or inhibition, with predominance of the latter, especially in the mouse advanced lesions (Lenzi et al., 1988; 1988a). Granulomas ultimately serve to protect the host from high local concentrations of foreign or "non-self" materials of both endogenous and exogenous origin (Adams, 1983), limiting antigen diffusion to the vascular system (Lenzi et al., 1988) and working as an important interface between the self (host) and the non-self (infectious organism). Granulomas also limit the "metastatic capability" of some infectious agents. Some instances of the granulomatous process are under control of immunologic regulation (Warren et al., 1967; Boros, 1976), and present maturative and involutive phases, where occurs a balance between synthesis and digestion of structural elements of the extracellular matrix (Dunn et al., 1977; Takahashi et al., 1980). The connective tissue reaction inside the granulomas, independently of the etiology, is initially characterized by a provisional stroma, and later on by a fibrous stroma, reflecting the events of early embryonic development (Sherman et al., 1980). The dynamism of the granuloma-

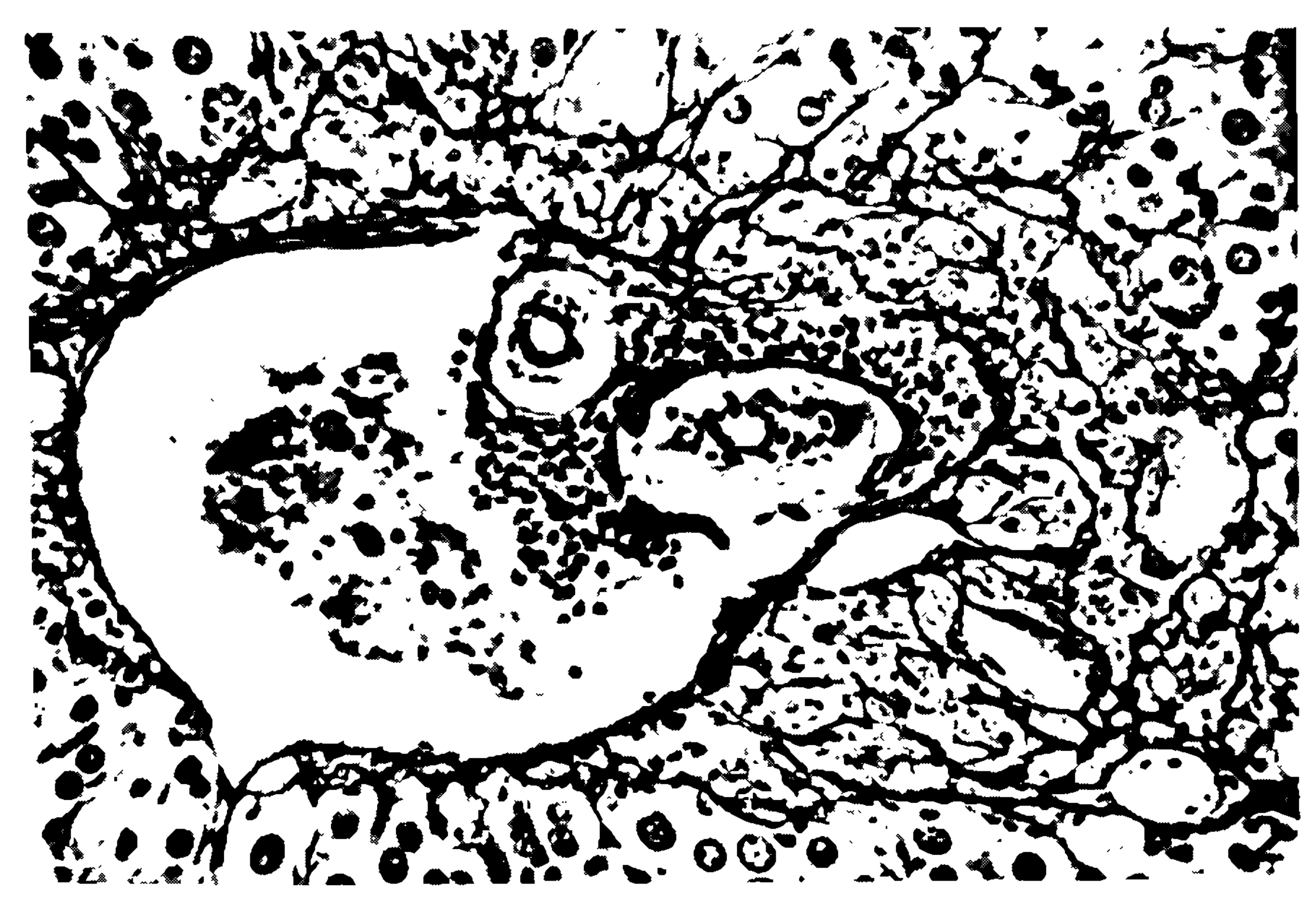

Fig. 2: two mature Schistosoma mansoni eggs in the lumen of portal vein, surrounded by cellular reaction. The cells interact with the wall of the vessel which is partially ruptured. Gomori's reticulum stain X 200 . 
tous process depends on the characteristic of the etiologic agent.

Etiological agent is intracellular - In this category are the infectious diseases in which the host-parasite relationship begins insidiously and, if untreated, continues until the death of the host, to which the parasite usually contributes significantly; instances of such chronic and severe hostparasite relations are tuberculosis, leprosy and syphilis (Pérez-Tamayo, 1985). Antunes (1989) studied the effects of leprous inflammatory lesions on the structure of dermal extracellular matrix components. The leprous lesions generally had scarce collagen fibers, except in lepromatous lesions, where the collagen fibers were deposited in higher amounts than in tuberculoid ones. There was a constant elastolysis in both lepromatous and tuberculoid lesions. The oxytalan and elaunin fibers in the dermal clear zone disappeared or were fragmented. This finding was associated with an atrophic epidermis above these fibers. Fibronectin showed a dense and diffuse fibril meshwork in tuberculoid or lepromatous lesions. The diffuse alcianophilic ground substance of the dermis was replaced for an irregular alcianophilic material embedding the inflammatory cells. Collagenesis, predominantly of collagen type III, in the lepromatous lesions was associated with local angiogenesis.

Etiological agent is intra and extracellular - Paracoccidioidomycosis, caused by Paracoccidioides brasiliensis is an example of this category. $P$. brasiliensis releases multiple buds from the parent cells by a pinching-off process similar to that seen in true yeast (Conant et al., 1971). The disease is characterized by a chronic granulomatous inflammation, with the involvement of several organs in its generalized form. Histopathology has revealed that the lesions are frequently accompanied by an intense fibrosis, sometimes causing severe visceral haemodynamic alterations, especially in the lungs, or abnormal mucocutaneous healing resulting in anatomical distortion, as in oropharynx (Tuder et al., 1985; Paula, 1962; Teixeira et al., 1978; Machado et al., 1965; Afonso et al, 1979; Campos et al., 1986). Ulsing

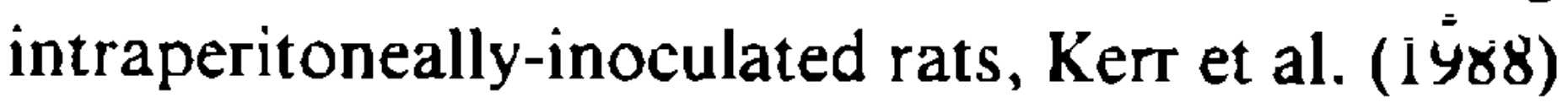
observed that both cellular and extracellular matrix components present during the inflammation were temporary elements which fluctuated in their role in the host's response to $P$. brasiliensis through the course of infection. Based on the results, these authors were able to divide the inflammatory process into three distinctive sequential stages: 1) neutrophilic or monocytic-neutrophilic stage (1 day after inoculation); 2) pre-granulomatous stage (days 2 and 3); and 3) granulomatous stage (starting on day 7). Synthesis of the extracellular matrix increased gradually, especially in the granulomatous stage and thereafter, and it started with the deposition of fibrin-like material as early as the neutrophilic stage, imitating the sequence of components of the matrix as seen in repair. During their development, the granulomas displayed their own extracellular matrix, made up of sulfated and acid proteoglycans, collagens types I and III, and reticular fibers. In the chronic phase of paracoccidioidomycosis (rat model), the granulomatous lesions were characterized by well-marked areas with the extracellular matrix showing quantitative and qualitative differences in its components (Kerr et al., 1988a). In fact, the extracellular space was com. posed of abundant collagen of types I and III. The granulomas were structurally arranged in two zones, one central containing fungi and the other peripheral. Type I predominated in the peripheral zone, showing a concentring pattern, while type III was randomly dispersed in both zones. The presence of collagen gradually increased from the center to the periphery of the granulomas, imparting a centrifugal direction to the fibrotic process. This amount of collagen was greater in the mature lesions than in the incipient ones, indicating that the sclerosis was not a static process. Kerr et al. (1988a) also observed the presence of proteoglycans, glycoproteins and a large amount of undefined substance. According to these authors, the heterogeneity of the extracellular matrix, and the active character of the fibroblasts, with abundant and enlarged rough endoplasmic reticulum, indicate the activity of the granulomatous lesions, even in the chronic stage.

Etiological agent is extracellular Schistosomal granuloma is the best example of this category. In experimental studies the lesions of Schistosoma japonicum have been found to be more acute and destructive than those of S. mansoni (Hsu et al., 1972; von Lichtenberg et al., 1971), and the subsequent fibrosis is more severe (von Lichtenberg et al, 1971). The evolution of the host response to schistosome eggs in experimental 
animals has been divided into five stages ( $\mathrm{Hsu}$ et al., 1972): a) Nonreactive or weakly reactive stage, when the egg is immature, at which time it gradually attracts mononuclear cells, neutrophils, and eosinophils; b) Exsudative stage, when the egg matures and is surrounded by a microabscess, with many neutrophils and some eosinophils; c) Exsudative productive stage, when histiocytes and epithelioid cells surround the egg and microabscess, and are, in turn, encircled by fibroblasts; d) Productive stage. The granuloma surrounding the egg consists of three zones: an inner zone of epithelioid cells, histiocytes, and occasional giant cells; a middle zone of fibroblasts and fibrocytes, and an outer zone of lymphocytes, hystiocytes, plasma cells, and sometimes eosinophils. The miracidium may be alive or dead during this stage; e) Involutional stage. The egg is reduced in size, and the shell is surrounded by some collagen fibers. The egg is usually disintegrated and may be calcified. Lenzi et al. (1987b) studying mice after 67,98 and 134 weeks of $S$. mansoni infection observed that the end-stage of the periovular reaction can present three different patterns: a) thick cicatricial; b) thin cicatricial (or residual cicatricial) and c) residual pigmented. These authors concluded that the granulomas can evolve to: a) a complete cure, remaining only the egg shells and pigmented macrophages; b) cicatricial healing with collagen $I$ and proteoglycans or only a minimum band of collagen I surrounding the egg shell (thin cicatricial).

Most of the experimentally produced stages described above can be seem in human biopsy or autopsy material.

The simultaneous secretion of cytokines and specific factors from the eggs acts on connective tissue cells and induces the local secretion of multiple connective matrix components (glycosaminoglycans, glycoproteins such as fibronectin, laminin, collagen isotypes) (Nishimura et al., 1985; Grimaud et al., 1987a; Grimaud, 1987). In the early beginning of the granuloma formation, fibronectin mainly produced by macrophages is present around the inflammatory cell as the major component of the matricial edifice concomitantly with heparan sulfate proteoglycan followed by deposition of interstitial collagens (type I and III) (Adnani, 1985; Grimaud et al., 1987a; Grimaud, 1987). Laminin and type IV collagen were conspicuous only in new vessels in the periphery of the granuloma (Parise et al., 1985).

Examination of the various collagen types within the lesions revealed organ differences as well as changes that occurred with the progress of the disease. A gradual increase in the amount of deposited collagen was observed within hepatic granulomas between 8-20 weeks (Grimaud et al., 1987a). According to them, at the early stage of the granulomatous response ( 8 weeks) type III collagen predominated within the large granulomas. With the onset of immunomodulation (10 weeks and onward), type I collagen became increasingly prominent. By the late chronic stage of the infection (16-20 weeks) type I and III collagens were present in equal amounts within the small granulomas. Type III collagen deposites in its precursor form, type III procollagen (Rojkind \& Kershenobish, 1981), and according to Wu et al. (1982), type III collagen is the predominant collagen in advanced murine schistosomiasis.

Olds et al. (1985) studied the dynamic of hepatic collagen biosynthesis and degradation in mice infected with S. japonicum. Early in infection, type I collagen was the predominant biosynthetic product, whereas late in infection type III collagen became the dominant isotype. A similar switch was seen in the substrate specificity of the constitutive collagenolytic activity, with decreasing type I activity and increasing type III activity as the disease progressed from acute (10 weeks) to chronic (30 weeks).

Type III collagen, fibronectin and a noncollagenous glycoprotein are the principal components of reticulin fibers (Unsworth et al., 1982) which are densely deposited around S. mansoni granuloma.

There is controversial with respect to the quantities and types of glycosaminoglycans found in different types of granulomas (Silva et al., 1989). Nishimura et al. (1985) found that quantities of hyaluronic acid, chondroitin-4-sulfate (and/or dermatan sulfate), chondroitin-6-sulfate in the isolated egg lesions significantly increased concomitantly with an extensive deposition of fibronectin and heparan sulfate proteoglycan. In the later stage, when granulomatous inflammation diminished leaving an empty egg shell, fibronectin and heparan sulfate proteoglycan disappear, and glycosaminoglycan contents decrease. In contrast, Junqueira et al. (1986) reported that dermatan sulfate was the only glycosaminoglycan detected in the granulomas and that its concentration increased during the evolution of the disease (50 to 100 days after infection). Olds et al. (1986) have shown that glycosaminoglycan synthesis increased considera- 
bly in granulomas of acute infection with $\boldsymbol{S}$. japonicum, and it decreased subsequently in the chronic phase of the infection. They have pointed out that glycosaminoglycan accumulation precedes the maximal collagen deposition by 4 to 6 weeks. Silva et al. (1989) showed that, as opposed to collagen, neither quantitative, nor qualitative differences could be observed between glycosaminoglycans obtained from granulomas in the acute and chronic phase of the disease. The major glycosaminoglycan isolated from both types of granulomas was dermatan sulfate; approximately $35-40 \%$ of total glycosaminoglycans was identified as heparan sulfate. Extracellular matrix of schistosome egg granuloma contains other components, including fibrin (Izaki et al., 1979) and complement (Andrade et al., 1961) that show an affinity of plasma fibronectin (Mosher, 1976; Bing et al., 1982).

Connective tissue cell population involved in peri-ovular fibrosis are probably of two distinct origins: locally activated fibroblasts (Grimaud \& Borojevic, 1977, 1986), and smooth muscle cells (Voss et al., 1982; Borojevic et al., 1985). Myofibroblasts present in the granuloma probably result from dedifferentiated smooth cells as evidenced by their desmin and $\alpha$-actin smooth muscle content. Inside the granuloma, fibroblasts and myofibroblasts are in close association to inflammatory cells while around the granuloma they delineate the limiting cellular plate with the parenchyma (Grimaud, 1987).

Reversibility of hepatic injury after treatment with specific chemotherapy has been previously reported in murine schistosomiasis (Cameron \& Ganguly, 1964; Schiller \& Haese, 1973; Morcos et al., 1985; Andrade \& Grimaud, 1986). Curative treatment of schistosomiasis does not induce something qualitatively new to the fibrous tissue in periovular granulomas. During the spontaneous evolution of the granulomas in the liver, it passes through phases of inflammation, increased fibrogenesis, death of the miracidium, and total or partial resorption of fibrosis. Chemotherapy turns these changes synchronized to all granulomas (Andrade, 1989). Soon after curative treatment, hepatic periovular granulomas start to involute, presenting an ultrastructural composite picture of fibroblast hyperplasia plus extracellular collagen breakdown and internalization or phagocytosis of collagen fragments by macrophages, fibroblasts, and myofibroblasts (Andrade \& Grimaud, 1986). After four and half weeks following chemotherapy, collagen in the remaining involuting granulomas shows different patterns of degradation, which suggests that after a period of acute changes, degradation of collagen proceeds at a slow rate. There are two main focal changes seen at ultrastructural level in densely packed collagen fibers: dissolution of groups of fibers leaving empty spaces or holes (lytic changes) and the transformation of the fibers into a finely granular or fibrilar electron dense material (electron-dense changes) (Andrade \& Grimaud, 1988; Andrade, 1989).

Schiltz et al. (1988) demonstrated that liver granulomas induced by $\mathbf{S}$. mansoni eggs synthesize collagens and glycosaminoglycans for about 4-6 weeks following parasitological cure. The subsequent resolution of granulomas proceeds first by a reduction in glycosaminoglycan biosynthesis followed 4-8 weeks later by decreased collagen biosynthesis, followed by accelerated resolution of both collagen and glycosaminoglycans. The decrease in collagen deposition was not observed when treatment (Praziquantel) was given 12 or 20 weeks postinfection. At this stage of infection granulomas were more fibrous, with an increase in the total collagen content (12 to 16 weeks postinfection), mainly of type I collagen as indicated by a decrease in the ratio of type III/I collagen (EIBadrawy et al., 1988).

During schistosomiasis, the fibrosis is not restricted to the eggs, but there are also portal (periportal), perivascular and lobular fibrosis (Bogliolo, 1957; Andrade, 1965; Grimaud, 1987).

Zwingenberger et al. (1988) have demonstrated that procollagen-III-peptide (P-III-P) is sensitive marker for hepatic involvement in human schistosomiasis due to $S$. mansoni. Circulating P. III-P reflects a net increase in collagen metabolism and may be associated with both synthesis and degradation, since the propeptide is partly retained and integrated into tissue collagen in precipitated fibrogenesis. In murine infections of S. manso$n i$, dense deposits of collagen type III precursor were demonstrated in granuloma (Parise et al., 1985). Serum P-III-P concentrations rose significantly after treatment with praziquantel in Zairean patients with hepatomegaly caused by $S$. manso . $n i$, suggesting release of propeptide previously incorporated without cleavage into tissue collagen (Zwingenberger et al., 1988a).

Bolarin et al. (1985) observed, during the active fibrotic stage of the development of murine hepatic schistosomiasis mansoni infection (weeks 7 to 10 ), 
dramatic changes in the serum and hepatic tissue galactosylhydroxylysyl glucosyltransferase (SGGT), tissue polyl hydroxylase and tissue hydroxylysyl galactosyltransferase acticities, which reflect the increased rate of collagen synthesis. The changes observed in S-GGT are significantly correlated with changes in liver.

\section{GRANULOMA AND EXTRAMEDULLARY HEMATOPOIESIS}

Hepatic schistosomal granulomas can build up a matricial edifice which works like bone-marrow stroma, facilitating extramedullary hematopoiesis. Hepatic eosinophil granulocytopoiesis or metaplsia was described by Goennert (1955), Grimaud \& Borojevic (1972), Byran et al. (1978) and Borojevic et al. (1981). It occurrs in the periphery of hepatic granulomas from 40th day on, showing a trimodal pattern, that roughly reproduces the eosinophil curve in bone marrow, attaining maximum intensity on 80th day after infection (Lenzi et al., 1987a; Lenzi \& Lenzi, 1990). The selective stimulation of eosinophilopoiesis and, more rare, of the neutrophil lineage, could be achieved either by progenitor selection or through specific stimulation of less differentiated stem cells (Borojevic et al., 1981). One possible hypothesis is that GranulocyteMacrophage Colony Stimulating Factor (GM-CSF) is bound to glycosaminoglycans in the supporting stroma of the hepatic granulomas, and is then released in hepatic microenvironment, where it acts on nearby progenitors.

\section{CELL INTERACTIONS WITH ECM}

Little is known about the interactions of different types of cells and extracellular matrix components inside the granulomas and granulation tissue caused by infectious and parasitic organisms. Wyler et al. (1987) suggests that strain-specific, autoimmune $\mathrm{T}$-cell reactivity directed against host matrix proteins might also contribute to granulomatous hypersensitivity. $T$ cells from infected C57B1/6, but not from CBA or BALB/c mice, proliferate in vitro in response to denaturated collagen. These observations indicate that anticollagen responses develop spontaneously in schistosome-infected mice and suggest that such reactivity might play a secondary role in granuloma formation and the pathogenesis of hepatic fibrosis. Preliminary results indicate that collagenspecific T cells from $S$. mansoni-infected mice se- crete fibrogenic molecules in vitro (Wyler, unpublished observations cited in Wyler et al., 1987).

Besides monocuclear phagocytes, neutrophils, eosinophils, T and B lymphocytes, plasma cells, mast cells, fibroblasts and myofibroblasts can be detected in the granulomas and granulation tissue. There are several examples of extracellular matrix components modulating lymphocyte behavior other than attachment to fibronectin, laminin, and collagen (Arencibia \& Sundqvist, 1989). For example, $T$ cells from rheumatoid subjects were stimulated to proliferate (Ofosu-Appiah et al., 1989) and synthesize IF- $\gamma$ in response to collagens, and this IF- $\gamma$ response was enhanced by fibronectin (OfosuAppiah et al., 1989a). Migration of lymphocytes through or on collagen matrices has also been noted (Schor et al., 1983; Haston et al., 1982), and soluble collagen appeared to enhance lymphocyte motility (Arencibia \& Sundqvist, 1989). In each of these cases, a potential role for integrins is implied but not demonstrated. More recently, two distinct receptors used by $\mathrm{T}$ lymphocytes and other cells for binding to distinct fibronectin sites have been identified (Wayner et al., 1989). Fibronectin and/or collagen altered gene expression or production of inflammatory mediators such as TNF- $\alpha, \mathrm{CSF}, \mathrm{PGE} 2$ and IL-1 in monocytes (Thorens et al., 1987; Eierman et al., 1989; Dayer et al., 1986). Both collagen and fibronectin are also chemotactic for human monocytes (Postlethwaite \& Kang, 1976; Norris et al., 1982). Together, these findings suggest that basement membrane matrix components and newly deposited fibronectin present at inflammatory sites can modulate monocyte/macrophage differentiation, and activation (Hemler, 1990). The presence of a large amount of VLA-6, and moderate VLA-4 and VLA-5 on monocytes is consistent with the substancial capability of the cells to attach to laminin-coated surfaces and their moderate ability to attach to fibronectin (Tobias et al., 1987). Monocytes also bind very well to elastin, a matrix component not yet found to be a ligand for any integrin-type receptor (Tobias et al., 1987). It remains to be determined if interactions of cells with matrix provides a signal transduced through integrin-type receptors directly, or if integrin receptors simply anchor cells in the proper tissue location, with a topological orientation that optimizes their response to other signals (Hemler, 1990).

\section{CONCLUSION}

Because of their strategic location, molecules of the extracellular matrix undoubtedly play an im- 
portant role in determining certain fundamental features that happen during host-parasite relationship. They can take part in crucial events of many infections, favouring the adherence of infectious organisms to different cells, and the penetration into the host. They also act as a mechanical barrier and have important trophic (permeability, filtration, ion exchange, etc.) and morphogenetic functions during the inflammatory reactions. Extracellular matrix on which the cells and infectious organisms sit is an extension of the cells and an active participant in the regulation of cellular function; i.e. the ECM is an "informational" entity in the sense that it receives, imparts and integrates structural and functional signals (Bissel \& BarcellosHoff, 1987). Bissel et al. (1982) proposed that the minimum unit of function is the cell plus its ECM. Therefore, the ECM matrix has, during the inflammatory process, important biological function by modulating cell migration, growth and differentiation. Influence of ECM is communicated through organization of the cytoskeleton (itself with connections to the nuclear matrix), possibly mediated by cell shape changes, which results in regulation of gene expression at all levels: transcription, mRNA processing, translation, post-translational modifications, secretion and extracellular organization (Bissel \& Barcellos-Hoff, 1987). During the granuloma and granulation tissue formation there is a metabolic turnover of ECM proteins, which is the result of two simultaneous but opposite processes: biosynthesis and degradation. Little is known about the direct influence of the parasites and infectious organisms on these events. Much work is needed to define exactly the disturbed regulation of connective tissue production in fibrosis. Certain parasites can induce fibroplasia and activate fibroblasts to produce and lay down excessive amount of connective tissue, as in liver fibrosis caused by $\mathbf{S}$. mansoni and in cardiac fibrosis due to $T$. cruzi infection (Andrade et al., 1989). Tuder et al. (1985), studying lungs from patients with paracoccidioidomycosis, found a intense fibrosis, and they suggested the possibility that the fungus itself might induce an active reticulin proliferation and that the collagen deposition could be evoked by a macrophage-fibroblast interaction. Fascio. la hepatica may chemically induce an increase in collagen synthesis through the release of proline (Modavi \& Isseroff, 1984).

The fibrosis around the chronic inflammatory lesions produces a capsular structure which can act as a barrier to antigen diffusion and, at the same time, can avoid the penetration of drugs. This aspect, together with the independent or au- tochtonous fibrotic mechanism, would explain the progressive cicatricial character of some parasitic lesions even without, or in spite of, therapy (Tuder et al., 1985; Restrepo et al., 1980).

Still is unknown the role of the antibodies directed against ECM components reported in a variety of infectious diseases (Zabriskie, 1971; Nagle et al., 1974; Szarfman et al., 1982). It is possible that an immunological cross-reaction exists between certain protein of pathogenic organisms and components of ECM. Distinct types of ECM components may at some point participate in a humoral and/or cellular immune response which may perpetuate some pathological conditions.

Independently of the etiological agent, the inflammatory-reparative process, due to parasitic or infectious agents, follows a sequence similar to the morphogenesis of an organ or tissue. The durability of the lesions depends on the life span and local reproductiveness of the parasitic and infectious organisms, which can be altered by the inflammatory and immune response of the host.

ECM components can sometimes be important to the parasite survival. For instance, the presence of glycosaminoglycans (or proteoglycans) which covers the surface of superficial epithelial cells of opossum odoriferous gland may in some way be involved in providing a facilitating environment for $T$. cruzi division and, due to their dense negative charge, may restrict the approach of the parasite to the epithelial cells (Lenzi et al., 1984).

\section{REFERENCES}

ABRAHAM, S. N.; BEACHEY, E. H. \& SIMPSON, W. A., 1983. Adherence of Streptococcus pyogenes, Escherichia coli and Pseudomonas aeruginosa to fibronectin-coated and uncoated epithelial cells. Infect. Immun., 41: 1261-1268.

ADAMS, D. O., 1983. The Biology of granuloma. p. 1-20. In H. L. Ioachim, Pathology of granulomas. Raven Press, New York.

ADNANI, M. S., 1985. Concomitant immunohistochemical localization of fibronectin and collagen in schistosome granulomata. J. Pathol., 147: 77-85.

AFONSO, J. E.; NERY, L. E.; ROMALDINI, H.; BOGOSSIAN, M. \& RIBEIRO-RATTO, O., 1979. Função pulmonar na paracoccidioidomicose (blastomicose sul-americana). Rev. Inst. Med. Trop. Säo Paulo, 21: 269-280.

ANDRADE, S. G.; GRIMAUD, J. A. \& STOCKERGUERRET, S., 1989. Sequential changes of the connective matrix components of the myocardium (fibronectin and laminin) and evolution of cardiac 
fibrosis in mice infected with Trypanosoma cruzi. Am. J. Med. Hyg., 40: 252-260.

ANDRADE, Z. A., 1965. Hepatic schistosomiasis. Morphological aspects. p. 228-242. In H. Popper, F. Schaffner, Progress in liver diseases. Vol. III. Grune \& Stration, New York.

ANDRADE, Z. A., 1989. Evolution and involution of hepatosplenic schistosomiasis. Mem. Inst. Oswaldo Cruz, 84 (Suppl. I): 58-75.

ANDRADE, Z. A. \& GRIMAUD, J. A., 1986. Evolution of the schistosomal hepatic lesions in mice after curative chemotherapy. Am. J. Pathol., 124: 59-65.

ANDRADE, Z. A. \& GRIMAUD, J. A., 1988. Morphology of chronic collagen resorption. A study on the late stages of schistosomal granuloma involution. Am. J. Pathol., 132: 389-399.

ANDRADE, Z. A.; PARONETTO, F. \& POPPER, H., 1961. Immunocytochemical studies in schistosomiasis. Am. J. Pathol., 99: 589-598.

ANTUNES, S. L. G., 1989. Repercussoes do processo inflamatório de etiologia hanseniana na biologia da pele. Enfoque especial na matriz extracelular e na trama vascular. Master Thesis. UFRJ, Rio de Janeiro, 174p.

ARENCIBIA, I. \& SUNDQVIST, K.-G., 1989. Collagen receptor on $\mathrm{T}$ lymphocytes and the control of lymphocyte motility. Eur. J. Immunol, 19: 929-934.

ASCH, H. L. \& DRESDEN, M. H., 1979. Acidic thiol proteinase activity of Schistosoma mansoni egg extracts. J. Parasitol., 65: 543-549.

AURIAULT, C.; PIERCE, R.; CESARI, 1. M. \& CAPRON, A., 1982. Neutral protease activities at different developmental stages of Schistosoma mansoni in mammalian hosts. Comp. Biochem. Physiol., T2B: 377-384.

AVILA, J. L.; ROJAS, M. \& RIEBER, M., 1984. Antibodies to laminin in American custaneous leishmaniasis. Infect. Immun., 49: 402-406.

AVILA, J. L.; ROJAS, M.; VELAZQUEZ-AVILA, G.; VAN DER MARK, H. \& TIMPL, R., 1986. Antibodies to basement membrane protein nidogen in Chagas' disease and american cutaneous leishmaniasis. $J$. Clin. Microbiol., 24: 775.778.

BING, D. H.; ALMEDA, S.; ISLIKER, H.; LAHAV, J. \& HYNES, R. O., 1982. Fibronectin binds to $C_{1} q$ component of complement. Proc. Natl Acad. Sci. USA, 79: 4198-4201.

BISSEL, M. J.; HALL, H. G. \& PARRY, G., 1982. How does the extracellular matrix direct gene expression. J. Theor. Biol., 99: 31-68.

BISSEL, M. J. \&. BARCELLOS-HOFF, M. H., 1987. The influence of extracellular matrix on gene expression: is structure the message? J. Cell. Sci. Suppl., 8: $327-343$.

BOGLIOLO, L., 1957. The anatomic picture of the liver in hepatosplenic schistosomiasis mansoni. Ann. Trop. Med. Parasitol., 51: 1-14.

BOLARIN, D. M.; BARKER, K. \& FULLER, G. C., 1985. Serum and liver enzymes of collagen synthesis in hepatic murine schistosomiasis mansoni. Trans. R. Soc. Trop. Med. Hyg., 79: 826-830.
BOROJEVIC, R.; STOCKER, S. \& GRIMAUD, J. A., 1981. Hepatic eosinophil granulocytopoiesis in murine experimental schistosomiasis mansoni. Br. J. Exp. Pathol., 68: 480-489.

BOROJEVIC, R.; VINHAS, S. A.; MONTEIRO, A. N. A.; DOMONT, G. B.; ZYNGIER, F. R. \& GRIMAUD, J. A., 1985. Liver connective tissue cells isolated from human schistosomal fibrosis on alcoholic cirrhosis represent a modified phenotype of muscle cells. Biol. Cell., 5s: 231-238.

BOROS, D. L., 1976. Schistosomiasis mansoni: a granulomatous diseases of cell mediated immune etioloy. Ann. N. Y. Acad. Sci., 878: 36-46.

BRETAÑA, A.; AVILA, J. L.; ARIAS-FLORES, M.; CONTRERAS, M. \& TAJIA, F. J., 1986. Trypanosoma cruzi and american Leishmania spp.: immunocytochemical localization of a laminin-like pro. tein in the plasma membrane. Exp. Parasitol., 61 : 168-175.

BYRAN, J. E.; IMOHIOSEN, E. A. E. \& LICHTENBERG, F. von, 1978. Tissue eosinophil proliferation and maturation in schistosome-infected mice and hamsters. Am. J. Trop. Med. Hyg., 27: 267-270.

CAMERON, G. R. \& GANGULY, N. C., 1964. An experimental study of the pathogenesis and reversibility of schistosomal hepatic fibrosis. J. Pathol. Bacteriol., 87: 217-237.

CAMPOS, E. P.; TORCHIO, L. N.; CATANEO, L. N. \& PEROTTI, L. A., 1986. Paracoccidioidomicose pulmonar agressiva, endotraqueíte estenosante e corpulmonale subagudo. Descrição de um caso. Rev. Inst. Med. Trop. São Paulo, 28: 185-189.

COURTNEY, H. S.; SIMPSON, W. A. \& BEACHEY, E. H., 1983. Binding of Streptococcal lipoteichoid acid to fatty acid-binding sites on human plasma fibronectin. J. Bacteriol., 15s: 763-770.

CONANT, N. F.; SMITH, D. T.; BAKER, R. D. \& CALlAWAY, J. L., 1971. Paracoccidioidomycosis. p. 134-160. In Norman F. Conant, et al. (eds). Mannual of clinical mycology. Srd edition, W. B. Saunders Company, Philadelphia.

$D A M I A N, R . T ., 198 \%$. The exploitation of host im. mune responses by parasites. J. Parasitol., 78: $1-13$.

DAYER, J. M.; RICARD-BLUM, S.; KAUFMANN, M. T. \& HERBAGE, D., 1986. Type IX collagen is a potent inducer of PGE 2 and interleukin 1 production by human monocyte macrophages. F EBS Lett., 198: 208-212.

DOENHOFF, M. J.; HASSOUNAH, O. A. \& LUCAS, S. B., 1985. Does the immunopathology induced by schistosome eggs potentiate parasite survival? I $m m u$ nology Today, 6: 203-206.

DOENHOFF, $M_{\text {. }}$ J.; HASSOUNAH, O.; MURANE, H.; BAIN, J. \& LUCAS, S., 1986. The Schistosome egg granuloma: immunopathology in the cause of host protection oroparasite survival. Trans. $R$. Soc. Trop. Med. Hy̆g:, 80: 503-514.

DOENHOFF, M. J.; MUSALLAM, R; BAIN, J. \& McGREGOR, A., 1978. Studies on the host-parasite relationship in Schistosoma mansoni-infected mice. 
The immunological dependence of parasite egg excretion. Immunology, 35: 771-778.

DOENHOFF, M. J.; PEARSON, S.; DUNNE, D. W.; BICKLE, Q.; LUCAS, S.; BAIN, J.; MUSALLAM, R. \& HASSOUNAH, O., 1981. Immunological control of hepatotoxicity and parasite egg excretion in Schistosoma mansoni infections: stage specificity of the reactivity of immune serum in T-cell deprived mice. Trans. R. Soc. Trop. Med. Hyg., 75: 41-53.

DUNN, M. A.; ROJKIND, M; WARREN, K. S.; HIATT, P. K.; RIFAS, L. \& SEIFTER, S., 1977. Liver collagen synthesis in murine schistosomiasis. $J$. Clin. Invest., 59: 666-674.

DUNNE, D. W.; HASSOUNAH, O.; MUSALLAM, R.; LUCAS, S.; PEPYS, M. B.; BALTZ, M. \& DOENHOFF, M., 1983. Mechanisms of Schistosoma mansoni egg excretion: parasitological observations in immunossupressed mice reconstituted with immune serum. Parasite Immunol., 5: 47-60.

EIERMAN, D. F.; JOHNSON, C. E. \& HASKILL, J. S., 1989. Human monocyte inflammatory mediator gene expression is selectively regulated by adherence substrates. J. Im munol., 148: 1970-1976.

EL-BADRAWY, N. M.; HASSANEIN, H. I.; BOFROS, S. S.; NAGY, F. M.; ABDALLAH, N. M. \& HERBAGE, D., 1988. Effect of praziquantel on hepatic fibrosis in experimental schistosomiasis mansoni. Exp. Mol. Pathol., 49: 151-160.

ESPERDEN, F.\& CLEMMENSEN, I., 1981. Clumping of Staphylococcus aureus by human fibronectin. Acta Pathol. Microbiol. Immunol. Scand. (B), 89: 317-321.

GADASI, H. \& KESSLER, E., 1983. Correlation of virulence and collagenolytic activity in Entamoeba histolytica. Infect. Immun., s9: 528-531.

GOENNERT, R., 1955. Schistosomiasis studien IV. Zur Pathologie der Schistosomiasis der maus. $\boldsymbol{Z}$. Troponmed. Parasitol., 6: 279-336.

GRIMAUD, J. A., 1987. Cell-matrix interactions in schistosomal portal fibrosis: a dynamic event. Mem. Inst. Oswaldo Cruz., 82 (Suppl. IV): 55-65.

GRIMAUD, J. A. \& BOROJEVIC, R., 1972. Mesenchyme et parenchyme hepatique dans la bilharziose experimentale à Schistosoma mansoni: metaplasie myéloide. C. R. Acad. Sci., 274: 897.

GRIMAUD, J. A. \& BOROJEVIC, R., 1977. Myofibroblasts in hepatic schistosomal fibrosis. Experimen. tia, ss: $890-892$.

GRIMAUD, J. A. \& BOROJEVIC, R., 1986. Portal fibrosis: intrahepatic portal vein pathology in chronic human schistosomiasis mansoni. J. Submicrosc. Cytol., 18: 783-793.

GRIMAUD, J. A.; BOROS, D. L.; TAKIYA, C.; MATHEW, R. C. \& EMONARD, H., 1987a. Collagen isotypes, laminim and fibronectin in granulomas of the liver and intestines of Schistosoma mansoniinfected mice. Am. J. Trop. Med. Hyg., \$7: 335-344.

HASTON, W. S.; SHIELDS, J. M. \& WILKINSON, P. C., 1982. Lymphocyte locomotion and attachment on two-dimensional surfaces and in three-dimensional matrices. J. Cell. Biol., 92: 747-752.

HEMLER, M. E., 1990. VLA proteins in the integrin family: structures, functions and their role on leukocytes. Annu. Rev. Immunol., 8: 365-400.

HOWARD, R. J. \& SHERWOOD, J. A., 1986. The altered membrane of malaria-infected erythrocytes: variable epitopes and immune evasion/conserved epitopes and cytoadherence. Mem. Inst. Oswaldo Cruz, 81 (Suppl. II): 95-109.

HSÜ, S. Y. L.; HSÜ, H. F.; DAVIS, J. R. \& LUST, G. L., 1972. Comparative studies on the lesions caused by eggs of Schistosoma japonicum and Schistosoma mansoni in livers of albino mice and rhesus monkeys. Ann. Trop. Med. Parasitol., 66: 89-97.

IZAKI, S.; FUKUYAMA, K. \& EPSTEIN, W. L., 1979. Modulation of antithrombin and antifibrinolytic activities in tissue during the development of granulomas by Schistosoma mansoni. J. Reticuloen. dothel. Soc., 26: 507-514.

JUNQUEIRA, L. C. U.; MONTES, G. S.; TOLEDO, O. M. S. \& JOAZEIRO, P. P., 1986. Morphological, histochemical and biochemical observations on the connective tissue matrix of in situ and isolated hepatic granulomas in experimental murine schistosomiasis. Ann. Trop. Med. Parasitol., 80: 27-41.

KEENE, W. E.; JEONG. K. H.; McKERROW, J. H. \& WERB, Z., 1983. Degradation of extracellular matrix by larvae of Schistosoma mansoni. II. Degradation by newly transformed and developing schistosomula. Lab. Invest., 49: 201-207.

KERR, I. B.; ARARIPE, J. R.; OLIVEIRA, P. C. \& LENZI, H. L., 1988. Paracoccidioidomycosis: a sequential histopathologic study of lesions in experimentally-infected rats. Rev. Inst. Med. Trop. São Paulo, s0: 336-350.

KERR, I. B.; OLIVEIRA, P. C. \& LENZI, H. L., 1988a. Connective matrix organization in chronic granulomas in experimental paracoccidioidomycosis. Mycopathologia, 10s: 11-20.

KLOETZL, K., 1967. A collagenase-like enzyme diffusing from eggs of Schistosoma mansoni. Trans. R. Soc. Trop. Med. Hyg., 61: 608-609.

KLOETZL, K, 1968. A collagenase-like substance produced by eggs of Schistosoma mansoni. $J$. Parasitol., 54: 177-178.

LENZI, H. L.; ARARIPE, J. R. \& KERR, 1. B., 1988. Intrinsic vascularization of granuloma in experimen. tal paracoccidioidomycosis. Brazilian J. Med. Biol. Res., 21: 945-947.

LENZI, H. L.; JANSEN, A. M. \& DEANE, M. P., 1984. The recent discovery of what might be a primordial escape mechanism for Trypanosoma cruzi. Mem. Inst. Oswaldo Cruz, 79 (Suppl.): 13-18.

LENZI, H. L. \& LENZI, J. A., 1990. Comparative distribution of eosinophils in bone marrow, blood and peritoneal cavity in murine schistosomiasis. Brazilian J. Med. Biol. Res., 2s: 989-994.

LENZI, H. L.; LENZI, J. A. \& SOBRAL, A. C. L., 1987. Eosinophils favor the passage of eggs to the intestinal lumen in schistosomiasis. Brazilian J. Med. 
Biol. Res., 80: 433-435.

LENZI, H. L.; SOBRAL, A. C. L. \& LENZI, J. A., 1987a. "In vivo" kinectics of eosinophils and mast cells in experimental murine schistosomiasis. $\mathrm{Mem}$. Inst. Oswaldo Cruz, 82 (Suppl. IV): 67-76.

LENZI, H. L.; SOBRAL, A. C. L. \& LENZI, J. A., $1987 \mathrm{~b}$. The fate of the granulomes in chronic murine schistosomiasis. Rev. Soc. Bras. Med. Trop., 20 (Suppl.): 37.

LENZI, H. L.; SOBRAL, A. C. L. \& LENZI, J. A., 1988a. Participation of endothelial cells in murine schistosomiasis. Brazilian J. Med. Biol. Res., 21: 999-1003.

LEWERT, R. M. \& LEE, C. L., 1954. Studies on the passage of helminth larvae through host tissues. $J$. Infec. Dis., 95: 13-51.

LIOTTA, L. A.; RAO, C. N. \& BARSKY, S., 1983 Tumor invasion and the extracellular matrix. $L a b$. Invest., 49: 636-649.

LOPES, J. D.; Da-MOTA, G. F. A.; CARNEIRO, C. R. W.; GOMES, L.; COSTA-E-SILVA-FILHO, F. \& BRENTANI, R. E., 1988. Evolutionary conservation of laminin-binding proteins. Brazilian J. Med. Biol. Res., 21: 1269-1273.

LOPES, J. D.; dos REIS, M. \& BRENTANI, R. E., 1985. Presence of laminin receptors in Staphylococcus aureus. Science, 289: 275-277.

MACHADO, J.; MIRANDA, J. L. \& TEIXEIRA, G. A., 1965. Das sequelas da blastomicose sul-americana. Hospital, 68: 141-147.

McKERROW, J. H.; JONES, P.; SAGE, H. \& PINOHEISS, S., 1985. Proteinases from invasive trematode parasite Schistosoma mansoni degrade connective tissue and basement-membrane macromolecules. $B i$ ochem. J., 291: 47-51.

MCKERROW, J. H.; PINO-HEISS, S.; LINQUIST, R. L. \& WERB, Z., 1986. Purification and characterization of an elastinolytic proteinase secreted by cercarie of Schistosoma mansoni. J. Biol. Chem., 260: 3703.3707 .

MODAVI, S. \& ISSEROFF, H., 1984. Fasciola hepatica: collagen deposition and other histopathology in the rat host's bile duct caused by the parasite and by proline infusion. Exp. Parasitol., 58: 239-244.

MORCOS, S. H.; KHAYYAL, M. T.; MANSOUR, M. M.; SALEH, S.; ISHAK, E. A.; GIRGIS, N. I. \& DUNN, M. A., 1985. Reversal of hepatic fibrosis after praziquantel therapy of murine schistosomiasis. Am. J. Trop. Med. Hyg., \$4: 314-321.

MOSHER, D. F., 1976. Action of fibrin-stabilizing factor on cold-insoluble globulin and $\alpha_{2}$-macroglobulin in clothing plasma. J. Biol. Chem., 251: 1639-1645.

MOSHER, D. F., 1980, Fibronectin. Prog. Hemost. Thromb., 5: 111-151.

MOSHER, D. F. \& PROCTOR, R. A., 1980. Binding and factor XIII-a-mediated cross-linking of a 27-Kilodalton fragment of fibronectin to Staphylococcus aureus. Science, 209: 927-929.

MUÑOZ, M. L.; CALDERON, J. \& ROJKIND, M., 1982. The collagenase of Entamoeba histolytica. J. Exp. Med., 155: 42-51.
NAGLE, R. B.; WARD, P. A.; LINDSLEY, H. B.; SADUM, E. H.; JOHNSON, A. J.; BERKAW, R. E. \& HILDEBRANDT, P. K., 1974. Experimental infections with african trypanosomes. VI. Glomerulonephritis involving the alternate pathway of complement activation. Am. J. Trop. Med. Hyg., 2s: 15-26.

NEWPORT, G.; McKERROW, J.; HEDSTROM, R.; CULPEPPER, J.; MCGARRIGLE, L. \& AGABIAN, N., 1987. Schistosome elastases: biological importance, structure, function and stage-specific expression. Biochem. Soc. Symp., 59: 115-121.

NISHIMURA, M.; ASAHI, M.; HAYASHI, M.; TAKAZONO, I.; TANAKA, Y.; KOHDA, H. \& URABE, H., 1985. Extracellular matrix in hepatic granulomas of mice infected with Schistosoma mansoni. Arch. Pathol. Lab. Med., 109. 813-818.

NOISIN, E. L. \& VILLALTA, F., 1989. Fibronectin increases Trypanosoma cruzi amastigote binding to and uptake by murine macrophages and human monocytes. Inf. Immun., 54: 1030-1034.

NORRIS, D. A.; CLARK, A. F.; SWIGART, L. M.; HUFF, J. C.; WESTON, W. L. \& HOWELL, S. E., 1982. Fibronectin fragment(s) are chemotactic for human peripheral blood monocytes. J. Immunol., 189: 1612-1618.

OFOSU-APPIAH, W. A.; WARRINGTON, R. J. \& WILKINS, J. A., 1989. Interleukin 2 responsive T cell clones from rheumatoid and normal subjects: proliferative responses to connective tissue elements. Clin. Immunol. Immunopathol., 50: 264-271.

OFOSU-APPIAH, W.; WARRINGTON, R. J.; MORGAN, K. \& WILKINS, J. A., 1989a. Lymphocyte extracellular matrix interactions. Induction of interferon by connective tissue components. Scand. J. Im. munol., 29: 517-525.

OLDS, G. R.; GRIFFIM, A. \& KRESINA, T. F., 1985. Dynamics of collagen accumulation and polymorphism in murine Schistosoma japonicum. Gas. troenterology, 89: 617-624.

OLDS, R. G.; FINEGAN, C.\& KRESINA, T. F., 1986. Extracellular matrix in hepatic granulomas of mice infected with Schistosoma mansoni. Arch. Pathol. Lab. Med., 109: 813-818.

OUAISSI, M. A.; AFCHAIN, D.; CAPRON, A. \& GRIMAUD, J. A., 1984. Fibronectin receptors on Trypanosoma cruzi trypomastigotes and their biological function. Nature, 308: 380-382.

OUAISSI, M. A.; CORNETTE, J. \& CAPRON, A., 1985. Trypanosoma cruzi: modulation of parasitecell interaction by plasma fibronectin. Eur. J. Im munol., 15: 1096-1101.

OUAISSI, M. A.; CORNETTE, J.; AFCHAIN D.; GRAS-MASSE, H. \& TARTAR, A., 1986. Trypanosoma cruzi infection inhibited by peptides modeled from a fibronectin cell attachment domain. Science, 294: 603-607.

OUAISSI, M. A.; CORNETTE, J. \& CAPRON, A., 1986a. Identification and isolation of Trypanosoma cruzi trypomastigote cell surface protein with properties expected of a fibronectin receptor. Mol. Bi. 
ochem. Parasitol., 19: 201-211.

PARISE, E. R.; SUMMERFIELD, J. A.; HAHN, E.; WIEDMAINN, K. H. \& DOENHOFF, M. J., 1985. Basement membrane proteins and type III procollagen in murine schistosomíasis. Trans. $R$. Soc. Trop. Med. Hyg., 79: 663-670.

PAULA, A., 1962. O pulmāo na blastomicose brasileira. Bol. Acad. Nac. Med., 1\$4: 40-43.

PÉREZ-TAMAYO, R., 1985. Mechanisms of disease. An Introduction to pathology. 2nd. ed. Year Book Medical Publishers Inc., Chicago, 652p.

PETERSON, K. M.; BASEMAN. J. B. \& ALDERETE, J. F., 1983. Treponema pallidum receptor binding proteins interact with fibronectin. J. Exp. Med., 15\%: 1958-1970.

PEYROL, S. M.; OUAISSI, A.; CAPRON, A. \& GRIMAUD, J. A., 1987. Trypanosoma cruzi: ultrastructural vascularization of fibronectin bound to culture cells. Exp. Parasitol., 6s: 112-114.

PINO-HEISS, S.; BROWN, M. \& McKERROW, J. H., 1985. Schistosoma mansoni: degradation of host extracellular matrix by eggs and miracidia. Exp. Parasitol., 59: 217-221.

PINO-HEISS, S.; PETITT, M.; BECKSTEAD, J. H. \& McKERROW, J. H., 1986. Preparation of mouse monoclonal antibodies and evidence for a host immune response to the preacetabular gland proteinase of Schistosoma mansoni cercariae. Am. J. Trop. Med. Hyg., \$5: 536-543.

POSTLETHWAITE, A. E. \& KANG, A. H., 1976. Collagen - and collagen peptide - induced chemotaxis of human blood monocytes. J. Exp. Med., 14s: 1299-1307.

RAPHAEL, G. D. \& METCALFE, D. D., 1986. Mediators of airway inflammation. Eur. J. Respir. Dis., 69 (Suppl. 147): 44-56.

REED, N. W. \& WILLIAMS, R. C., 1978. Bacterial adherence: first step in the pathogenesis of certain infections. J. Chronic. Dis., s1: 67-92.

RESTREPO, A.; STEVENS, D. A.; GOMEZ, I.; LEIDERMAN, E.; ANGEL, R.; FUENTES, J.; ARANA, A.; MEJIA, G.; VANEGAS, A. C. \& ROBLEDO, M., 1980. Ketoconazole: a new drug for the treatment of paracoccidioidomycosis. Rev. Infect. Dis., 2: 633.642.

ROBERTS, D. D.; SHERWOOD, J. A.; SPITALNIK, S. L.; PANTON, L. J.; HOWARD, R. J.; DIXIT, V. M.; FRAZIER, W. A.; MILLER, L. H. \& GINSBURG, V., 1985. Thrombospondin binds falciparum malaria parasitized erythrocytes and may mediate cytoadherence. Nature, 918: 64-69.

ROJKIND, M. \& KERSHENOBISH, D., 1981. Hepatic fibrosis. Clin. Gastroenterol., 10: 737.754.

RYDEN, C.; RUBIN, K.; SPEZIALE, P.; HÖÖK, M.; LINDBERG, M. \& WADSTROM, T., 1983. Fibronectin receptors from Staphylococcus aureus. J. Biol. Chem., 258: 3396-3401.

SCHILLER, E. L. \& HAESE, W. H., 1973. Histologic processes of healing in hepatic injury due to eggs of Schistosoma mansoni in mice following curative chemotherapy. Am. J. Trop. Med. Hyg., 28:
$211-214$

SCHITZ, J. R.; OLDS, G. R.; KRESINA, T. F.\& MAHMOUD, A. A. F., 1988. Effect of chemotherapy on hepatic collagen and glycosaminoglycan metabolism in Schistosoma mansoni-infected mice. Trans. $R$. Soc. Trop. Med. Hyg., 88: 868-873.

SCHOR, S. L.; ALLEN, T. D. \& WINN, B., 1983. Lymphocyte migration into Three-dimensional collagen matrices: a quantitative study. J. Cell. Biol., 96: 1089-1096.

SHERMAN, M. 1.; GAY, R.; GAY, S. \& MILLER, E. J., 1980. Association of collagen with preimplantation and peri-implantation mouse embryos. Dev. Biol., 74: 470-478.

SILVA FILHO, F. C.; SOUZA, N.; LOPES, J. D. \& BRENTANI, R. E., 1986. Influence of fibronectin and laminin on the adhesive properties of Trichomonads. Mem. Inst. Oswaldo Cruz, 81, Suppl. p. 200

SILVA, L. C. F. da; MOURÃO, P. A. S. \& BOROJEVIC, R., 1989. Patterns of sulfated glycosaminoglycan synthesis and accumulation in hepatic granulomas induced by schistosomal infection. Exp. MoL Pathol., 50: 411.420 .

SIMPSON, W. A.; HASTY, D. L.; MASON, J. M. \& BEACHY, E. H., 1982. Fibronectin mediated attachment of group A streptococci to human PMNs. Infect. Immun., s7: 805-810.

SMITH, M. A., 1974. Radioassays for the proteolytic enzyme secreted by living eggs of Schistosoma man. soni. Int. J. Parasitol., 4: 681-683.

SPEZIALE, P.; HOOK, M.; WADSTROM, T.\& TIMPLE, R., 1982. Binding of the basement membrane protein laminin to $E$. coli. FEBS Lett., 146 : 55-58.

STIREWALT, M. A., 1974. Schistosoma mansoni: cercaria to schistosomule. Adv. Parasitol., 12: 115-182.

STIREWALT, M., 1982. Biochemical and physiological aspects of skin penetration by schistosomes. $p$. 132-143. In G. T. Strickland \& K. W. Hunter Jr. Im. munoparasitology - principles and methods in malaria and schistosomiasis research. Praeger Publishers, USA.

SZARFMAN, A.; TERRANOVA, V. P.; RENNARD, S. I.; FOIDART, J. M.; de FATIMA LIMA, M.; SCHEINMAN, J. 1. \& MARTIN, G. R., 1982. Antibodies to laminin in Chagas' disease. J. Exp. Med., 155: 1161-117I.

TAKAHASHI, S.; DUNN, M. A. \& SEIFTER, S., 1980. Liver collagenase in murine schistosomiasis. Gastroenterology, 78: 1425-1431.

TEIXEIRA, F.; GAYOTTO, L. C. \& BRITO, T., 1978. Morphological patterns of the liver in south american blastomycosis. Histopathology, 2: 231-237.

THORENS, B.; MERMOD, J. J. \& VASSALLI, P., 1987. Phagocytosis and inflammatory stimuli induce GM-CSF mRNA in macrophages through posttranscriptional regulation. Cell, 48: 671-679.

TOBIAS, J. W.; BERN, M. M.; NETLAND, P. A. \& ZETTER, B. R., 1987. Monocyte ädhesion to subendothelial components. Blood, 69: 1265-1268. 
TORRES, M.\& PINTO, C., 1945. Lesões produzidas pelo S. mansoni no tatu ( $E$. sexcinctus), mecanismo de eliminação dos ovos e sensibilidade da espécie animal nas infecçōes experimentais. Mem. Inst. Os. waldo Cruz, 4s: 301-348.

TOWBIN, H.; ROSENFELDER, G.; WIESLANDER, J.; AVILA, J. L.; ROJAS, M.; SZARFMAN, A; ESSER, K.; NOWACK, H. \& TIMPL, R., 1987. Circulating antibodies to mouse laminin in Chagas' disease, american cutaneous leishmaniasis, and normal individuals recognize terminal galactosyl ( $\alpha 1-3)$ galactose epitopes. J. Exp. Med., 166: 419.432.

TRUDEN, J. L. \& BOROS, D. L., 1985. Collagenase, elastase and nonspecific protease production by vigorous on immunomodulated liver granulomas acid granuloma macrophages/eosinophils of S. mansoniinfected mice. Am. J. Pathol., 121: 166-175.

TUDER, R. M.; EL IBRAHIM, R.; GODOY, C. E. \& BRITO, T., 1985. Pathology of the human pulmonary paracoccidioidomycosis. Mycopathologia, 98: 179-188.

UNSWORTH, D. J.; SCOTT, D. L.; ALMOND, T. J.; BEARD, H. K.; HOLBOROW, E. J. \& WALTON, K. W., 1982. Studies on reticulin I. Serological and immunohistological investigation of the occurrence of collagen type III, fibronectin and the non-collagenous glycoprotein of Pras and Glynn in reticulin. J. $\boldsymbol{E x p}$. Pathol., 68: 154-166.

VERCELLOTTI, G. M.; MCCARTHY, J. B.; LINDHOLM, P.; PETERSON, P. K.; JACOB, H. S. \& FURCHUT, L. T., 1985. Extracellular matrix proteins (fibronectin, laminin and type IV collagen) bind and aggregate bacteria. $A m$. J. Pathol., 120: 13.21. VON LICHTENBERG, F.; SADUN, E. H.; CHEEVER, A. W.; ERICKSON, D. G.; JOHNSON, A. J. \& BOYCE, H. W., 1971. Experimental infection with Schistosoma japonicum in chimpanzees. $A m$. J. Trop. Med. Hyg., 20: 850-893.

VOSS, B.; RAUTERBERG, J.; POTT, G.; BREHMER, U.; ALLANM, S.; LEHMANN, R. \& VON BASSEWITZ, D. B., 1982. Non parenchymal cells cultivated from explants of fibrotic liver resemble endothelial and smooth muscle cells from vessel walls. Hepatology, 8: 19.28.

WARREN, K. S.; DOMINGO, E. O. \& COWAN, R.
B. T., 1967. Granuloma formation around schistosome eggs as a manifestation of delayed hypersensitivity. Am. J. Pathol., 51: 735-756.

WAYNER, E. A.; GARCIA-PARDO, A.; HUMPHRIES, M. J.; MCDONALD, J. A. \& CARTER, W. G., 1989. Identification and characterization of the lymphocyte adhesion receptor for an alternative cell attachment domain in plasma fibronectin. J. Cell. Biol., 109: 1321-1330.

WIRTH, J. J.\& KIERSZENBAUM, F., 1984. Fibronectin enhances macrophage association with invasive forms of Trypanosoma cruzi. J. Immunol., 199: 460-464.

WU, C. H.; GIAMBRONE, M. A.; HOWARD, D. J.; ROJKIND, M. \& WU, G. Y., 1982. The nature of collagen in hepatic fibrosis in advanced murine schistosomiasis. Hepatology, 2: 366-369.

WYLER, D. J.; SYPEK, J. P. \& MCDONALD, J. A., 1985. In vitro parasite-monocyte interactions in human leishmaniasis: possible role of fibronectin in parasite attachment. Infect. Immun., 49: 305-311.

WYLER, D. J.; LAMMIE, P. J.; MICHAEL, A. I.; ROSENWASSER, L. J. \& PHILLIPS, S. M., 1987. In vitro and in vivo evidence that autoimmune reactivity to collagen develops spontaneously in Schisto. soma mansoni-infected mice. Clin. Immunol. Immunopathol., 44: 140-148.

ZABRISKIE, J. B., 1971. The role of streptococci in human glomerulonephritis. J. Exp. Med., 154: 180-192.

ZWINGENBERGER， K.; FELDMEIER， H.; NOGUEIRA QUEIROZ, J. A.; VERGETTI SIQUEIRA, J. G.; FARIAS AUTO, H.; ALENCAR, J. E. \& BIENZLE, U., 1988. Liver involvement in human schistosomiasis mansoni. Assessment by immunological and biochemical markers. Parasitol. Res., 74: 448-455.

ZWINGENBERGER, K.; HARMS, G.; FELDMEIER, H.; MÜLLER, O.; STEINER, A. \& BIENZLE, U., 1988a. Liver involvement in human schistosomiasis mansoni. Regression of immunological and biochemical disease markers after specific treatment. Acta Trop., 45: 263-275. 